\title{
PERBEDAAN PENGETAHUAN SEBELUM DAN SESUDAH DIBERIKAN PENDIDIKAN KESEHATAN IUD PASCA PLASENTA DI RSUD PURBALINGGA
}

\author{
Ima Syamrotul Muflihah ${ }^{1,}$ Diah Atmarina Yuliani ${ }^{2}$ \\ ${ }^{1}$ Fakultas Ilmu Kesehatan, Universitas Muhammadiyah Purwokerto \\ ima.syamrotul@gmail.com \\ ${ }^{2}$ Fakultas Ilmu Kesehatan, Universitas Muhammadiyah Purwokerto \\ yuliani_da@yahoo.com
}

\begin{abstract}
Contraceptives can be used in postpartum and the most potential to prevent mis opportunity are Intrauterine Device (IUD) or IUD. Post-placental IUD using in the first 10 minutes to 48 hours after placenta (or before uterine I uterine suture in postpartum and post-miscarriage) in the health facility. The result of preliminary study showed that $20 \%$ of mothers already know about postplacenta IUD (20\%), and 4 others do not know about postplacenta IUD (80\%). The purpose of this research is to determine the differences in knowledge before and after health education in post-placental IUD. The method in this research is quasy experiment on maternity mother at RSUD Goeteng Tarunadibrata Purbalingga for 3 (three) months with p-value $<0.00$. The results showed that have difference of knowledge before and after health education about IUD post-placenta. The mothers expected to active in exploring the knowledge and information in choosing the most of effective contraceptive and then sharing with her husband.
\end{abstract}

Keywords: knowledge, helath education, post-placental IUD

\section{PENDAHULUAN}

Penggunaan kontrasepsi di Indonesia masih didominasi metode kontrasepsi hormonal dan bersifat jangka pendek yang pada umumnya memiliki continuation rate yang rendah dibandingkan dengan metode kontrasepsi jangka panjang. Rendahnya penggunaan kontrasepsi jangka panjang dipengaruhi oleh faktor pengguna dan penyedia pelayanan KB. Salah satu faktor yang dianggap berkontribusi dengan kecenderungan pemilihan metode jangka pendek adalah faktor penerimaan atau image terhadap kontrasepsi tersebut dan belum optimalnya informasi kontrasepsi jangka panjang (Riskesdas, 2014). Kesulitan dalam menentukan metode kontrasepsi yang akan digunakan oleh wanita pascasalin disebabkan karena kurangnya informasi dan konseling tentang metode kontrasepsi yang tepat sesuai dengan kebutuhan dan kondisi kesehatannya.
(Chandradewi, 2013)

Konseling merupakan aspek yang sangat penting dalam pelayanan keluarga berencana dan kesehatan reproduksi, seringkali konseling diabaikan dan tidak dilaksanakan dengan baik karena petugas tidak ada waktu dan tidak menyadari pentingnya konseling. Padahal dengan informasi yang lengkap dan cukup akan memberikan kesempatan pada klien untuk memilih kontrasepsi yang akan digunakan, sehingga klien merasa puas dan pada akhirnya dapat meningkatkan keberhasilan program KB. Berdasarkan data Profil Dinas Kesehatan Kabupaten Banyumas tahun 2015 akseptor KB Aktif sebanyak 222.654. Peserta KB pasca salin yang menggunakan suntik 139.456 orang, IUD 32.908 orang, implant 30.364 , pil 30.517 orang, MOW 9.117, kondom 9.010 orang, MOP 1.799, yang menggunakan KB pasca 
salin hanya 2.376 orang.

Alat Kontrasepsi Dalam Rahim (AKDR) pascaplasenta adalah program dimana klien mendapat insersi AKDR 10 menit setelah plasenta lahir, dapat dilakukan pada persalinan spontan maupun sectio caesaria. Adapun keuntungan dari kontrasepsi IUD pascaplasenta adalah pasien dapat menggunakan kontrasepsi segera setelah melahirkan sehingga mengurangi rasa takut pada saat pemasangan, sangat efektif karena tidak perlu mengingat-ingat, metode jangka panjang dan tidak mempengaruhi ASI (Saefuddin, 2010). Berdasarkan rekomendasi dari The National Meeting on Family Planning Programs pada tahun 2008 dalam Jurnal Media Bina Ilmiah (2013), KB Pasca Plasenta merupakan salah satu program utama yang harus tersedia diseluruh provinsi. Oleh karena itu penelitian ini dilakukan untuk mengetahui perbedaan pengetahuan tentang IUD Pasca plasenta sebelum dan sesudah diberikan pendidikan kesehatan tentang IUD Pasca Plasenta (DinKesProp Jateng, 2015).

Hasil studi pendahuluan melalui wawancara pada 5 orang pasien inpartu didapatkan 1 (20\%) orang ibu sudah mengetahui tentang KB IUD pasca plasenta, dan $4(80 \%)$ orang ibu belum mengetahui tentang KB IUD pascaplasenta. Berdasarkan latar belakang uraian diatas penulis tertarik untuk melakukan penelitian tentang "Perbedaan Pengetahuan Sebelum dan Sesudah Diberikan Pendidikan Kesehatan Tentang IUD Pasca Plasenta di Rumah Sakit Umum Daerah Goeteng Tarunadibrata Purbalingga"

\section{METODOLOGI PENELITIAN}

Penelitian ini dilakukan di RSUD Goeteng Tarunadibrata. Desain penelitian yang digunakan adalah quasy eksperiment. Populasi dalam penelitian ini adalah seluruh ibu bersalin yang melahirkan di Bangsal Kebidanan RSUD Goeteng Tarunadibrata mulai bulan Oktober sampai Desember 2016 dengan total sampling sebanyak $30 \mathrm{ibu}$ bersalin. (Arikunto, 2000).

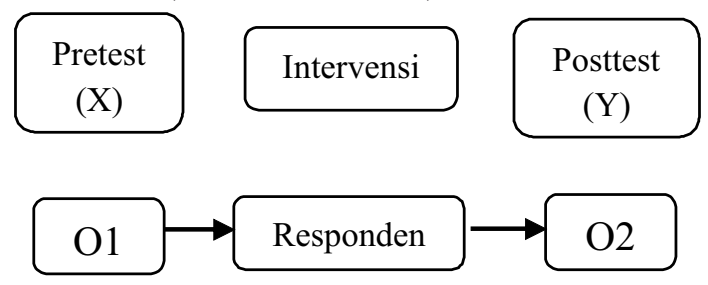

Keterangan :

$\mathrm{X}=$ Pretest pengetahuan ibu tentang iud pasca plasenta

$\mathrm{A}=$ Pemberian konseling IUD pasca plasenta $\mathrm{Y}=$ Posttest pengetahuan ibu tentang IUD Pasca Plasenta

Analisis univariat digunakan untuk menjelaskan/ mendiskripsikan karakteristik masing-masing variabel yang diteliti (Arikunto, 2000). Variabel yang dianalisis secara univariat dalam penelitian ini adalah pengetahuan dan motivasi sebelum dan sesudah konseling.

Analisis bivariat digunakan untuk menguji hubungan antara dua variabel. Analisis bivariat dilakukan untuk membuktikan hipotesis penelitian yaitu melihat perbedaan pengetahuan ibu rumah tangga sebelum dan sesudah diberikan konseling kontrasepsi IUD pasca plasenta. Analisis bivariat dilakukan dengan uji statistik, bila $\mathrm{p}$-value $\leq 0,05 \mathrm{Ho}$ 
ditolak, maka ada perbedaan pengetahuan Ibu sebelum dan sesudah diberikan konseling kontrasepsi IUD pasca plasenta. Bila $p$-value $>$ 0,05 Ho gagal ditolak, maka tidak ada perbedaan pengetahuan ibu sebelum dan sesudah diberikan konseling iud pasca plasenta.

\section{HASIL DAN PEMBAHASAN}

\section{a. Karakteristik Responden}

\section{1) Umur Ibu}

Umur berhubungan dengan struktur organ, fungsi faal, system hormonal seorang wanita. Distribusi umur ibu bersalin yang diberikan konseling $\mathrm{KB}$ dalam penelitian ini terdapat pada table berikut :

Tabel 1. Distribusi responden berdasarkan umur ibu

\begin{tabular}{|l|c|c|}
\hline \multicolumn{1}{|c|}{ Umur } & $\mathrm{N}$ & $\%$ \\
\hline$<20$ tahun & 7 & 23.33 \\
\hline $20-35$ tahun & 21 & 70.00 \\
\hline$>35$ tahun & 2 & 6.66 \\
\hline Jumlah & 30 & 100 \\
\hline
\end{tabular}

Tabel di atas menunjukkan persentase terbesar untuk karakteristik usia pada rentang 25 - 30 tahun sebanyak $70.00 \%$. Hal ini menunjukkan bahwa sebagian besar reponden pada rentang usia produktif. Usia reproduktif adalah usia aman bagi wanita untuk hamil sehingga pada usia ini seseorang hanya merencanakan alat kontrasepsi yang bertujuan untuk mengatur kehamilan.

\section{2) Pendidikan Ibu}

Pendidikan merupakan proses pengubahan sikap dan tata laku seseorang atau kelompok orang dalam usaha mendewasakan manusia melalui upaya pengajaran dan pelatihan. Pendidikan seseorang dikelompokkan menjadi beberapa tingkat pendidikannya yaitu pendidikan dasar (SD, SMP), pendidikan menengah (SMA), pendidikan tinggi (akademik, perguruan tinggi). Distribusi pendidikan ibu bersalin yang diberikan konseling KB dalam penelitian terdapat dalam tabel berikut :

Tabel 2. Distribusi responden berdasarkan pendidikan ibu

\begin{tabular}{|l|c|c|}
\hline $\begin{array}{c}\text { Tingkat } \\
\text { pendidikan }\end{array}$ & $\mathrm{N}$ & $\%$ \\
\hline Dasar (SD,SMP) & 8 & 26.67 \\
\hline Menengah (SMA) & 17 & 56.66 \\
\hline $\begin{array}{l}\text { Tinggi } \\
\text { (Akademik, PT) }\end{array}$ & 5 & 16.67 \\
\hline \begin{tabular}{l} 
Jumlah \\
\hline
\end{tabular}
\end{tabular}

Tabel di atas menunjukkan persentase terbesar untuk karakteristik pendidikan yaitu pendidikan dasar (SD,SMP) sebanyak $26.66 \%$. Tingkat pendidikan merupakan salah satu faktor predisposisi yang mempengaruhi minat dan perilaku seseorang.

\section{b. Pengaruh pemberian konseling KB IUD pasca plasenta terhadap pemilihan alat kontrasepsi iud pasca plasenta.}

Perbedaan pengetahuan ibu sebelum dan sesudah diberikan konseling IUD pasca plasenta dapat dilihat pada tabel 3 berikut: 
Tabel 3. Perbedaan pengetahuan ibu sebelum dan sesudah diberikan konseling IUD pasca plasenta

\begin{tabular}{|l|l|c|}
\hline Variabel & \multicolumn{1}{|c|}{ Mean SD } & P value \\
\hline Sebelum & $39.77(7.77)$ & \multirow{2}{*}{0.000} \\
\hline Sesudah & $80.00(6.54)$ & \\
\hline & Selisih: 1.23 & \\
\hline
\end{tabular}

Berdasarkan Tabel 3 menunjukkan bahwa rata - rata pengetahuan ibu sebelum dan sesudah diberikan konseling IUD pasca plasenta meningkat 1.23 dengan hasil $p$-value $<0.00$ sehingga dapat disimpulkan terdapat pengaruh pemberian konseling IUD pasca plasenta terhadap pemakaian IUD pasca plasenta.

Berdasarkan hasil penelitian, hasil pengolahan data tahap penilaian pengetahuan sebelum dan sesudah diberikan pendidikan kesehatan tentang IUD pasca plasenta menunjukkan perbedaan secara bermakna. Hal ini menunjukkan bahwa pendidikan kesehatan tentang IUD pasca plasenta efektif untuk meningkatkan pengetahuan ibu tentang IUD pascaplasenta. Hasil ini sesuai dengan penelitian Cahya Wibawa (2007) yang menyatakan bahwa pengetahuan dapat diperoleh dari pengalaman, guru, orangtua, buku dan media masa. Selain itu juga sesuai dengan pendapat Notoatmodjo (2010) yang menyatakan bahwa dengan promosi kesehatan, yaitu semua sarana atau upaya untuk menampilkan pesan atau informasi yang ingin disampaikan oleh fasilitator baik itu melalui media cetak, elektronik, maupun media luar ruang dapat meningkatkan pengetahuan yang akhirnya diikuti dengan perubahan sikap terhadap kesehatan.
Fasilitator merupakan unsur manusiawi dalam pembelajaran. Kehadiran fasilitator mutlak diperlukan didalamnya. Kalau hanya ada peserta pelatihan tetapi fasilitator tidak ada maka tidak akan terjadi pembelajaran. Jangankan ketiadaan fasilitator, kekurangan fasilitator juga sudah merupakan hambatan dalam pemberian pendidikan kesehatan. Permasalahan fasilitator merupakan dimensi yang luas, tidak hanya bersentuhan dengan masalah diluar dirinya seperti mampu berhubungan baik dengan peserta belajar dan lingkungan belajar lainnya. Menjadi fasilitator tidak dapat diandalkan dari bakat atau hasrat saja namun disertai kegiatan studi dan latihan serta pengalaman yang memadai agar muncul sikap fasilitator yang diinginkan dan menyenangkan (Wibawa C, 2010)

Berdasarkan penelitian Tumini (2010) didapatkan hasil terdapat perbedaan kemantapan pemilihan alat kontrasepsi IUD Pasca Plasenta pada kelompok yang diberikan konseling. Didukung oleh penelitian Chandradewi (2013) bahwa terdapat perbedaan signifikan rata-rata nilai pengetahuan ibu tentang IUD Pasca Plasenta setelah diberikan konseling KB sehingga dapat disimpulkan terdapat pengaruh pemberian konseling alat kontrasepsi IUD Pasca Plasenta dengan pemilihan alat kontrasepsi IUD Pasca Plasenta. Memberikan intervensi pendidikan kesehatan tentang IUD Pasca Plasenta artinya memberikan tambahan informasi sehingga meningkatkan pengetahuan ibu. Peningkatan pengetahuan tersebut mempengaruhi motivasi pengambilan keputusan untuk menggunakan alat kontrasepsi IUD Pasca Plasenta sesuai 
dengan kebutuhan dan keadaannya ibu.

\section{SIMPULAN DAN SARAN}

\section{a. Simpulan}

Simpulan penelitian ini yaitu sebagian besar karakteristik umur ibu yang diberikan pendidikan kesehatan tentang KB IUD Pasca plasenta yaitu 20-35 tahun sebanyak 70\%. Pemilihan kontrasepsi sebelum diberikan pendidikan kesehatan sebagian besar memilih non IUD pasca plasenta, nemun setelah diberikan pendidikan kesehatan sebagian besar ibu memilih kontrasepsi IUD pasca plasenta sebanyak $90 \%$. Terdapat perbedaan pengetahuan sebelum dan sesudah diberikan pendidikan kesehatan IUD pasca plasenta dengan $p$-value $<0.00$.

\section{b. Saran}

Ibu diharapkan berperan aktif dalam menggali pengetahuan dan informasi dalam pemilihan alat kontrasepsi yang paling efektif kemudian disharingkan dengan suami. Dengan adanya dukungan dan peran suami seperti adat dan budaya yang ada di Indonesia bahwa keputusan sebagian besar ada pada suami maka akan berpengaruh terhadap motivasi dalam pemilihan alat kontrasepsi.

\section{DAFTAR PUSTAKA}

Affandi. 2010. Kontrasepsi Intra Uterine Device (IUD) Baru. Jakarta. Jaya Press.

Arikunto, S. 2000. Prosedur Penelitian. Jakarta. Rhineka Cipta.

Creswell, J. 2014. Research Design. California. SAGA.
Chandradewi, dkk. Pengaruh Pemberian Konseling Keluarga Berencana (KB) Terhadap Alat Kontrasepsi IUD Post Plasenta di RSUP NTB. 2013. Media Bina Ilmiah No.5 (7-12). ISSN No.1978-3787.

Kementrian Kesehatan Republik Indonesia. 2014. Profil Kesehatan Indonesia. Jakarta: Kementrian Kesehatan Republik Indonesia.

Manuaba, I. G. B. 2008. Ilmu Kebidanan, Penyakit Kandungan dan Keluarga Berencana Untuk Pendidikan Bidan. Jakarta. EGC.

Notoatmodjo, S. 2010. Metodologi Penelitian. PT. Rhineka Cipta Jakarta.

Prawirohardjo, S. 2000. Buku Acuan Nasional Pelayanan Maternal Neonatal. Jakarta. Bina Pustaka.

Ratih, I. 2010. Komunukasi Kebidanan. Jakarta. EGC

RPJMN. 2014. Pedoman pelayanan konseling. Jakarta. Kementerian Kesehatan.

Rianto, A. 2015. Aspek Hukum Dalam Penelitian. Jakarta. Yayasan Pustaka Obor Indonesia.

Riskesdas. 2014. Profil Kesehatan Kabupaten Banyumas. Dinas Kesehatan Provinsi Jawa Tengah.

Saeffudin, B. 2010. Gaya Hidup Masa Kini. Jakarta. PT. Gaya Favorit pres.

Tumini. Pengaruh Pemberian Konseling KB terhadap Pengetahuan tentang KB dan Kemantapan dalam Pemilihan KB. Surakarta. 2010.

Wibawa C. Perbedaan efektifitas metode demontrasi dengan pemutaran video tentang pemberantasan demam berdarah terhadap peningkatan pengetahuan dan sikap anak SD di kecamatan Wedarijaksa. Jurnal Promosi Kesehatan Indonesia. 2007;2(2):115-29. 